\title{
FACTORS CULTIVATING SUSTAINABLE ONLINE COMMUNITIES FOR K-12 TEACHER PROFESSIONAL DEVELOPMENT*
}

\author{
JUNG WON HUR \\ Indiana University, Bloomington \\ NORIKO HARA, PH.D. \\ Indiana University, Bloomington
}

\begin{abstract}
The purpose of this study is to discover factors related to fostering a sustainable online community for K-12 teachers. This study was conducted through the investigation of an online teacher community called INDISCHOOL in Korea. Data were gathered through in-depth telephone interviews with INDISCHOOL members, the examination of archived postings on the Web-boards, and participant observations. Twelve factors, including eight support factors and four hindrance factors, were identified as results of this study. These factors were categorized into three subgroups: internal, external, and outcome factors. Findings from this study revealed that internal factors, such as having a sense of ownership and autonomy and acknowledging the value of participation, played a significant role in the growth of INDISCHOOL. It was also noted that the value of teachers' participation was related to their belief that active involvement in INDISCHOOL improves student learning. These teachers also reported that INDISCHOOL participation is a valuable part of their professional development.
\end{abstract}

*This study was made possible with the help from the INDISCHOOL teachers. The editor, Robert Seidman, and anonymous reviewers provided helpful insights and comments. 


\section{INTRODUCTION}

Teachers face multiple challenges. New content area standards are changing expectations about the school learning experience (Goldman, 2001), and technologically savvy students ask teachers to utilize new technology in various ways (Department of Education, 2004). As a way to overcome the challenges, teachers are expected to be life-long learners through participation in teacher professional development programs. However, numerous researchers attest that the existing teacher professional development programs have not met teachers' professional needs (Barnett, 2002; Schlager \& Fusco, 2003; Sugar, 2005). For instance, no follow-up support is provided after one time workshops, and trainings are often disconnected from actual classroom practice (Schlager \& Schank, 1997).

The creation and utilization of teacher communities and encouragement of teacher collaboration are frequently suggested as means to foster teacher professional development (Little, 2002; Westheimer, 1998). In particular, the idea of creating online teacher communities has become popular, because of the flexibility of time and location (Schlager \& Fusco, 2003). Although many researchers have attempted to create online teacher communities, few such communities were sustained over an extended period of time (Zhao \& Rop, 2002). Consequently, the information regarding the formation of online communities is mostly descriptive and little is known about the development process of online communities (Schwen \& Hara, 2003). Furthermore, factors that affect fostering sustainable online teacher communities have not been explicitly investigated (Barab, MaKinster, Moore, \& Cunningham, 2001).

Consequently, the purpose of this article is to examine the following question: What are the factors that affect fostering a sustainable online community for K-12 teacher professional development? To examine this question, we investigated an online teacher community called INDISCHOOL (www.indischool.com) in Korea.

We begin this article with a description of social learning theory and community of practice, which serve as theoretical frameworks for examining online communities. Then, we describe the characteristics of the INDISCHOOL community, including its brief history and the levels of members. After the descriptions of the methodologies of the study, we provide our findings, including factors that foster or hinder teacher participation in INDISCHOOL. We conclude this article by discussing the implications of the identified factors and limitations of the study.

\section{LITERATURE REVIEW}

Social learning theory, such as situated learning theory and distributed cognition, and the concept of communities of practice have been widely applied as fundamental frameworks for examining communities for K-12 teacher professional development (Franklin \& Sessoms, 2005; Keller, Bonk, \& Hew, 2005). In this section, we define the theory and concept, further providing the characteristics 
of communities of practice. We conclude the section by presenting previous research findings.

\section{Social Learning Theory}

Situated learning theory was posited by Brown, Collins, and Duguid (1989) who cautioned that knowledge learned in schools is not transferred to the real world because of the separation of knowledge and activities. Through the analysis of exemplary learning, they came to believe that knowledge can only be fully understood through its use in real contexts. Situated learning theorists also emphasize that learning is not the acquisition of knowledge inside the mind; rather, it is the collaborative activity (Rogoff, 1994; Wenger, 1998) that takes place through participation in social activities, such as sharing and negotiation (McLellan, 1996).

Distributed cognition theorists propose that knowledge is distributed across people and tools, resulting in collective knowledge which is greater than the sum of individual knowledge (Johnson, 2001; Putnam \& Borko, 2000; Salmon, 1993). Perhaps Hutchins (1991) metaphorical description of this concept as akin to the navigation of a U.S. Navy ship best illustrates the approach: as knowledge about piloting the ship is distributed among several people, successful navigation must rely on group collaboration using several cognitive tools. Borko (2004) also defines learning as "changes in participation in socially organized activities, and an individual's use of knowledge as an aspect of their participation in social practice" (p. 4). Furthermore, Cobb (1994) explains that learning is composed of both a process of individual knowledge construction and enculturation into society.

To sum up, social learning theory expands learning to include the social nature of learning in which learning takes place through participation in communities of practice.

\section{Communities of Practice}

Communities of practice are viewed as self-organizing, evolving, and selfsustaining entities that are connected by shared problems and specific areas of interest to members (Ardichvili, Page, \& Wentling, 2002; Lave \& Wenger, 1991; Schlager \& Fusco, 2003). Wenger (1998) contends that communities cannot be designed since they are self-organizing in response to the needs of their users. The sustainability of communities is dependent on local ownership and member identification. Therefore, to sustain itself, the communities must have members who are committed and motivated (Barab, MaKinster, \& Scheckler, 2003).

Ellis, Oldridge, and Vasconcelos (2004) point out that even though a community is organized with special purposes in a particular context, what brings members together and sustains their relationships in the community is a voluntary 
commitment to pursuing common goals and visions embedded in the community. These researchers further explain that communities of practice are developed through sharing history, interests, and identity.

One of the vital concepts of communities of practice as defined by Lave and Wenger (1991) is "legitimate peripheral participation" (pp. 35-37). Through observation of different apprenticeships, they found that newcomers participate peripherally yet legitimately in a community. As they learn to become members of the community they move toward central participation in the socio-cultural practice.

Researchers have attempted to create online communities based on the belief that participation in an online teacher community would enhance teacher professional development (Barab et al., 2001). In the following section, we describe the factors that previous studies identified with regard to building online communities.

\section{Previous Research Findings}

Many researchers (e.g., Ardichvili et al., 2002) attest that having a sense of trust is essential to building online communities. Kling and Courtright (2003) recognize that developing trust requires constant reciprocal sharing and continual communication. Johnson (2001) contends that people are more likely to share their stories if they know people in person; thus, having offline meetings is important to assist online collaborations.

Protection of security and confidentiality is also widely emphasized. Ardichvili et al. (2003) argue that one of the reasons people do not participate in online discussion is because they are afraid that what they post may not be important, accurate, or relevant to a specific topic. Thompson (2005) claims that if members feel insecure about their personal information or their postings, they will not participate in online communities.

In a teacher community, having a sense of trust and security is especially critical. Grossman, Wineburg, and Woolworth (2001) found that providing a public stage where teachers share their teaching strategies or ideas might result in long-standing conflicts where, at best, innovative teachers are dubbed eccentric or, worse, teacher credibility is called into question. Similarly, teachers who question traditional teaching strategies may be viewed as incompetent teachers.

Schlager and Schank (1997) posit that to develop online communities there must be a "critical mass" of members actively participating in the community. Dubé, Bourhis, and Jacob (2005) assert that the devotion of community leaders and assistants are the key factors for the successful creation and development of sustainable communities. Over the course of monitoring an adult learning online community, Gray (2004) found that the role of online moderators is critical to fostering healthy online communities. 


\section{CONTEXT OF THE STUDY}

Based on the literature review, we found one of the reasons for sparse community sustainability was due to the fact that the communities were not selforganized by community members; rather, they were created by researchers with specific study purposes. We thus investigated the INDISCHOOL community; not only as it was created by teachers but also because it fits the characteristics of communities of practice, including shared knowledge and beliefs, a supportive culture, engagement in knowledge building, a group of practitioners, and informal interaction (Barab et al., 2003; Hara, 2000). In this section, we provide a history of INDISCHOOL and explain the levels of community members.

\section{History of INDISCHOOL}

In 1997, the Korean government initiated the "Information and Communication Technology (ICT) into Elementary and Secondary Education" plan (Ministry of Education, 2003), providing all K-12 schools in Korea with personal computers and Internet access. The plan was completed in 2000, making Korea the first nation in the world to connect all of their schools via the Internet (Ministry of Education, 2003). This technology infrastructure allows Korean teachers to utilize the Internet in a variety of ways, such as incorporating diverse multimedia resources into classes and building class Websites. Some teachers started creating Websites for other educators and provided various teaching ideas and materials through the Websites. As these sites were gaining popular among Korean teachers, many teachers were increasingly motivated to build additional Websites for other teachers.

The INDISCHOOL community was initiated by Byung Gun Park, a Korean elementary school teacher, who owned a popular Website for teachers. According to an interview with Mr. Park, he had realized from his Website that the flow of information was limited to one direction - from the Website owner to site visitors. He began to believe that the concept of an online community could be useful for teachers to reciprocate communications. He thus contacted the teachers who owned educator-oriented Websites and suggested that they collaborate in building an online community together. In 2000, Mr. Park created INDISCHOOL in conjunction with seven teachers who agreed with his proposal. For over five years, the INDISCHOOL community has been greatly evolving. As of December 2005, over 87,000 teachers had become members of INDISCHOOL, which constitutes approximately $54 \%$ of elementary school teachers in Korea (Korea National Center for Education Statistics \& Information, 2004). A variety of resources, teaching ideas, and personal stories are shared throughout its 100 Web-boards. All tasks, such as managing the Website, planning offline workshops, and monitoring Web-boards, are completed by volunteer members, and even the server maintenance fee is funded by donations from the community members. 


\section{INDISCHOOL Members}

Wenger (1998) indicates that community members have different levels of participation because the interests of each member vary. Based on the participation levels of the community, INDISCHOOL members can be largely divided into four groups: managers, active members, regular members, and lurkers. Currently, there are 10 managers, and over 35 members work for INDISCHOOL as active members. Though the precise number of regular members is not known, the server log file shows that more than 15,000 members visited the site per day at the time of the study in 2005. Figure 1 represents the levels of participation in INDISCHOOL.

Circles represent strong participation in INDISCHOOL by managers and active members. To distinguish weaker participation from the regular members and lurkers, a rounded square and square were used to denote the regular members and lurkers, respectively.

The first group, managers, includes Mr. Park, the Website managers, and offline workshop organizers. They plan various activities for members and regularly discuss ways to improve the community through online and offline meetings. The teachers in the second group, we call active members, volunteer to moderate Web-boards or initiate offline meetings. They frequently share their resources or reply to other members' questions. The third group includes members who regularly access INDISCHOOL but do not actively work for the community; they are called regular members. The last group, termed lurkers, only accesses the community when they need information but never share their own resources or ideas.

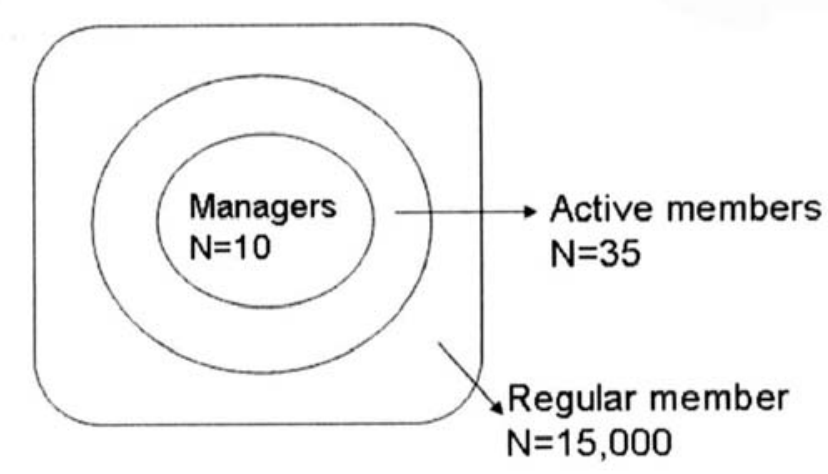

Lurkers

Figure 1. Levels of participation in INDISCHOOL. 


\section{METHODOLOGY}

To explore the complexity and detailed teacher experiences in the community, we utilized a single case study (Stake, 1995). It is an instrumental case study in that our intention is to identify factors influencing the sustainable nature of the online community, INDISCHOOL, rather than to understand the community itself. We wanted to find these factors by exploring teachers' perspectives of their participation because unless they found the participation valuable they would not participate in the community and the community would disappear. In other words, active participation is a key to the sustainability of the community, teachers must not only come to a community but also share their opinions within it. Consequently, we drew the factors influencing the sustainability of INDISCHOOL from our understanding of teachers' perspectives on their participation in the community. The questions that helped us solicit teachers' perspectives included why they wanted to create this community, why teachers continue (or not) to participate in the community, and how their participation influences teaching. Due to the qualitative nature of the questions, data were primarily gathered through in-depth telephone interviews with INDISCHOOL members. To ensure the trustworthiness of our study (Lincoln \& Guba, 1985), we examined the archived postings on the Web-boards. As an elementary school teacher in Korea, the first author has participated in the community for over one-and-a-half years taking notes over this duration. As a result, three sets of data were collected for this study, including interview transcriptions, archived Web-board postings, and researcher's observation notes.

\section{Participants}

In accordance with Silverman's (2001) emphasis on the importance of obtaining multiple perspectives when conducting interviews, we invited several members in each group to conduct interviews. We first contacted the 10 managers by e-mail. Six of them agreed to participate, but one teacher later declined to participate due to her busy schedule. Eight active members were then invited to telephone interviews and six of them participated. While we were observing the Web-boards, we noticed that many members were novice teachers who have less than three years teaching experience. For this reason, we purposefully selected 10 novice teachers. Two novice teachers who were identified as regular members participated in the interviews. We also randomly selected 15 teachers, four of whom (three are regular members while one is a lurker) agreed to participate. The first author also interviewed her acquaintance, a lurker of INDISCHOOL. One manager recommended contacting a community consultant - a middle school math teacher as well as the initiator of another online teacher community in Korea. The difference between the two communities is that the members of INDISCHOOL are elementary school teachers, whereas the other community includes all K-12 school teachers, wherein the largest percent of the population are 
middle or high school teachers. The consultant has helped manage INDISCHOOL since its inception.

In total, five managers, six active members, five regular members, two lurkers, and one community consultant participated in the interviews.

\section{Data Collection Methods}

\section{Interviews}

The interviews were conducted to explore motivations for participation, perceptions toward INDISCHOOL, experiences in the community, and impacts of participation (see Appendix 1 for the initial interview questions). To facilitate participants' meaning-making processes, a semi-structured interview format was utilized (Holstein \& Gubrium, 1995). For purposes of triangulation (Stake, 1995), the first author examined messages and teaching resources that interviewees uploaded before interviews. She then asked some specific questions with regard to the postings during the interviews. Interviews, which lasted between 30 minutes and two hours, were conducted from May 2005 to July 2005. Data were collected and transcribed in Korean, and quotes used in this article were translated into English.

We intended to conduct interviews via phone but three participants expressed preference for an instant messenger program conversation or e-mail with a written questionnaire. Consequently, an interview with a manager was conducted through an instant messenger, and two active members provided answers in the given question sheets. The lurker interview data were collected through two e-mail exchanges. He did not want to participate either in a telephone interview or fill out the question sheet. He simply described when he accessed the community site and why he did not participate in the community in his reply. We tried to ask follow-up questions but could not reach him again.

\section{Examinations of Archived Postings on Web-Boards}

To triangulate the data gathered through interviews and to understand the activities that teachers participated in, we examined the archived postings on the INDISCHOOL Web-boards between March 2002 and March 2004. As we could not examine all of the thousands of postings which were archived, we sorted out only the postings that were viewed by a large number of teachers or had received significant responses.

\section{Participation in Discussion}

It is important to note that the first author was an elementary school teacher in Korea and came to know the community in 2001. She became a member of the community in November 2004 and has participated in the community ever since. She has visited the site at least once a week and read and replied to other members' postings. She frequently visited the "Teacher Journal," "Free Talk," and 
"Web-board for Fifth Grade Teachers" boards because of the popularity of postings and frequent interactions among participants. She took notes related to the topics of the postings and teachers' perspectives while participating in the community.

\section{Data Analysis}

We adapted the constant comparison technique (Glaser \& Strauss, 1967) to analyze the collected data. While transcribing the interview data, we continued to find some themes that the interviewees commonly addressed. We developed codes for these themes and compared them with new data, such as other interview transcriptions and researcher notes. For the analysis of archived postings, we read through the postings and described the emerging themes. Later, we compared the themes of postings and interview codes and developed new codes that represented both the codes and themes. We called the new codes factors and divided them into several categories.

We examined the accuracy of our interpretations through peer debriefing and member checks (Carspecken, 1996). For the peer debriefing, we received help from a Korean doctoral student who had over 10 years of elementary school teaching experience in Korea. He read both original data and our interpretations and critiqued them. The factors names were modified slightly after the peer debriefing. For the member checks, we e-mailed three interviewees and asked them about the viability of our interpretations.

\section{FINDINGS}

We found that the factors contributing to the sustainability of INDISCHOOL were largely divided into two categories: support and hindrance factors. Within each category, the factors were also divided into three subgroups: internal, external, and outcome factors. We designated a factor as internal if the elements we found were controlled by members' perceptions, such as a sense of ownership. We called a factor an external factor if the elements could be controlled by outside components, such as technology. During the analysis process, we also found that some elements did not directly affect teachers' participation in the community yet were constantly recognized as factors. For example, we realized that novice teachers became more confident educators through the participation in INDISCHOOL. However, the factor itself did not directly influence teacher participation. Our interpretation was that although some elements did not increase teacher participation, when teachers recognized the components positively or negatively, it encouraged or discouraged teacher participation in INDISCHOOL. For instance, when novice teachers realized that their teaching skills and knowledge were enhanced through participation in the community, they were more likely to participate in the community in an active way. In other words, 
components which indirectly affected teacher participation in the community, we termed as outcome factors. We summarize the findings in Table 1 and discuss each factor in the following sections.

\section{Support-Internal Factors}

First, we describe the eight support factors that influence the sustainability of INDISCHOOL in the three subgroups listed in Table 1. We explain the three support-internal factors first.

\section{Having the Autonomy}

According to Mr. Park, he named INDISCHOOL ("independent" + "school") to emphasize the autonomy of the community. He realized that the compulsory command from the government sometimes prevented teachers from self-growing and free-sharing. In addition, many existing education-related Websites supported by companies were commercially utilized and depended on private funding. $\mathrm{He}$

Table 1. Factors Affecting a Sustainable Online Teacher Community

\begin{tabular}{|c|c|c|}
\hline \multirow[b]{2}{*}{ Subgroups } & \multicolumn{2}{|c|}{ Category } \\
\hline & Support factors & Hindrance factors \\
\hline \multirow[t]{3}{*}{$\begin{array}{l}\text { Internal } \\
\text { factors }\end{array}$} & 1. Having the autonomy & $\begin{array}{l}\text { 9. Teachers' lack of } \\
\text { confidence }\end{array}$ \\
\hline & 2. Having a sense of ownership & \\
\hline & $\begin{array}{l}\text { 3. Acknowledging values of } \\
\text { participation }\end{array}$ & $\begin{array}{l}\text { 10. Previous negative } \\
\text { experience in online } \\
\text { communities }\end{array}$ \\
\hline \multirow[t]{2}{*}{$\begin{array}{l}\text { External } \\
\text { factors }\end{array}$} & $\begin{array}{l}\text { 4. Providing online and offline } \\
\text { interaction }\end{array}$ & $\begin{array}{l}\text { 11. Lack of technological } \\
\text { support }\end{array}$ \\
\hline & $\begin{array}{l}\text { 5. Providing an easy way to use } \\
\text { technology systems }\end{array}$ & $\begin{array}{l}\text { 12. Discouraging teachers' } \\
\text { active learning }\end{array}$ \\
\hline \multirow[t]{3}{*}{$\begin{array}{l}\text { Outcome } \\
\text { factors }\end{array}$} & $\begin{array}{l}\text { 6. Helping novice teachers become } \\
\text { confident educators }\end{array}$ & \\
\hline & $\begin{array}{l}\text { 7. Assisting in overcoming teacher } \\
\text { isolation }\end{array}$ & \\
\hline & 8. Meeting teachers' individual needs & \\
\hline
\end{tabular}


thus chose the adjective of "independent" to highlight the independence of the community from the government and companies.

Donations from members enabled INDISCHOOL to have financial autonomy. In February 2004, the INDISCHOOL Website was completely unavailable because the server company that had supported INDISCHOOL at no cost went out of business. Several companies that considered advertising their business proposed to support INDISCHOOL. However, managers turned down all proposals because of their strong belief that company involvement would ruin the autonomy of the community. To maintain support, they decided to gather donations from teachers. As soon as the decision was reported, over 150 teachers donated small amounts of money with the promise of future monthly donations. Due to the number of donors which has been gradually increasing since April 2004, there is a special Web-board called donation, which is for sharing opinions on donation. The examinations of the postings on this Web-board indicated that many teachers agreed that financially securing the community was very important to keep the community alive. This example is consistent with the findings from George, Iacono, and Kling (1995) who argue that employing a grassroots implementation strategy and providing autonomy are keys to foster communities of practice.

\section{Having a Sense of Ownership}

The autonomy also provided members with a strong sense of ownership. The interview and observation data consistently showed that member teachers felt a strong sense of ownership of the community. When asked "How would you define the INDISCHOOL community?," an active member teacher, who has eight years of experience, answered, "A community that is of the teachers, for the teachers and by the teachers." Similarly, other respondents answered that the owners of the community were all member teachers in the community. All participants also acknowledged that without each teacher's voluntary support, the INDISCHOOL community could not be sustained.

To help more members have a strong sense of ownership, INDISCHOOL invited voluntary Web-board moderators every year, whose responsibilities included commenting on messages that other teachers posted, welcoming new members, and recommending good postings. Managers who participated in the interviews indicated that this strategy helped avoid a small group of people dominating the community and allowed more members to have a stronger sense of ownership of the community.

\section{Acknowledging Values of Participation}

We found that when teachers realized the value of participation, they were willing to actively participate in the community, which was invariably reflected in one of two ways. The first came from the teachers' belief that participation in 
the online community could result in self-learning. One regular member teacher, who has 10 years experience, mentioned:

Participation in teacher professional development programs is not always easy. I should be in a specific location, and if I do not have specific interests, I do not even try to participate in a program. However, while I was reading other teachers' postings on INDISCHOOL Web-boards, I learn something that I have never thought of, which helped me improve new skills.

The second was related to teachers' perception that students learned better with the resources and ideas that they gained from INDISCHOOL. All respondents of the interviews had experience applying ideas from INDISCHOOL and realized that students learned new knowledge in a more engaging and creative way. From the Web-board postings, we also found that numerous replies of postings were related to teachers' experiences and opinions: how they applied what they gained from INDISCHOOL to the classes and how useful they were. Because teachers often infused their success stories with reflection, teachers who read the postings were more likely to successfully implement the new teaching strategies with some modifications. A regular member teacher, who has two years of teaching experiences, expressed:

I am very satisfied with the quality of ideas and resources that INDISCHOOL members provide. I strongly believe that applying the ideas and resources that I gain from INDISCHOOL enhance the quality of teaching. For example, I applied an idea that an INDISCHOOL member shared in my art class. It was about presenting various elements on a black cardboard by using toothpick. My students loved the activity, and I thought that it helped students develop creative thinking skills.

\section{Support-External Factors}

Next, we discuss two support factors that are external to the community.

\section{Providing Online and Offline Interactions}

All the managers who participated in the interviews consistently emphasized the importance of offline meetings to create an active community. When initiators first created the community, it suffered from low participation prompting initiators to use various strategies to stimulate the community, such as offering many comments on newcomers' messages and restricting their own postings so that other teachers would write more. However, until they provided offline workshops, the community had remained nearly inactive. From their own experience of attending workshops organized by the government, initiators realized that teachers preferred to learn practical aspects of teaching strategies as opposed to theorydriven lectures, which were normally provided by the government-initiated workshops. The first INDISCHOOL workshop, which was held by one of the 
initiators in 2001, highlighted practical applications for classroom teaching. During the workshop, the managers introduced INDISCHOOL and asked the attendants to frequently visit the site. The attendants, who appreciated the efforts of the managers, started frequently visiting the site and sharing their stories and ideas. As more people participated in the community, resources and ideas became richer and, as a result, the number of newcomers and participation in general continued to increase. This case showed the importance of hybrid learning, providing both online and face-to-face instruction to facilitate learning in online environments (DeLacey \& Leonard, 2002).

\section{Providing an Easy Way to Use Technology Systems}

The technological aspect, especially its ease of use and flexibility, is recognized as an important factor to foster activities of INDISCHOOL. According to the interview with Mr. Park, as the community evolved, the teachers' needs grew as well. For example, teachers wanted to have more specialized discussion boards, such as a Web-board for married women, a digital picture sharing place, and members' blogs sharing space. Consequently, as new requests came up, the Web manager created new Web-boards. The current multi-board system is designed to easily add or modify a new Web-board and help the managers easily organize the online community. To our inquiry as to whether they have encountered any special technical problems, most interviewees reported that using the systems was easy and did not present any special problems.

\section{Support-Outcome Factors}

We further found three support factors that indirectly influenced teacher participation in INDISCHOOL.

\section{Helping Novice Teachers Become Confident Educators}

Through the interviews, we found that novice teachers were becoming confident educators in the process of participating in INDISCHOOL. An interview with a regular member teacher, who has two years of teaching experience, also pointed out, "Reading other teachers' postings not only helped me prepare lesson plans but also encouraged me to apply innovative teaching ideas to my class."

Another interesting finding was that INDISCHOOL assisted novice teachers who did not go through official teacher training courses. In 1998, the Prime Minister of the Ministry of Education amended the teacher retirement age from 65 to 62 . This resulted in a serious shortage of teachers during the following year. To fill the vacancies, the Ministry of Education allowed people with secondary teaching licenses to apply for the elementary school teacher examination in 1999 and 2000. The applicants who passed the exam became elementary school teachers after three months of training. 
Two participants with secondary teacher licenses mentioned that they came to INDISCHOOL to learn classroom management and appropriate teaching strategies for elementary school students. Because of the isolated school culture (Little, 2002), asking fellow teachers about teaching tips or classroom management strategies was problematic. The countless pieces of advice from the INDISCHOOL members and teaching ideas available through INDISCHOOL Webboards greatly assisted them in becoming confident elementary school teachers.

\section{Assisting in Overcoming Teacher Isolation}

The interviewees often mentioned that it was challenging to meet other teachers who could share their teaching ideas or concerns in their local schools. The hierarchical school structure, where decisions were made based on level of position or amount of teaching experience, also hindered free discussion among colleagues (Ingersoll, 2003). INDISCHOOL, however, facilitated diverse interactions, as members were willing to share ideas and provide informative advice regardless of their level of teaching experience. An active member with five years of teaching experience stated:

In my first year of teaching, I was very disappointed by the closed school culture. I would like to ask many things to fellow teachers, but it seemed that they were reluctant to help me. Honestly, I sometimes wanted to quit the job. However, the openness of INDISCHOOL allowed me to see things differently. I was amazed by the willingness of members and the sharing culture of INDISCHOOL. Whenever I have questions now, I just go to INDISCHOOL. It provides everything that I need.

\section{Meeting Teachers' Individual Needs}

From our interview data, we noted that the reason teachers continued to participate in the community was because their individual needs, however varied, were met in INDISCHOOL. An active teacher, who has 13 years of teaching experience, expressed that INDISCHOOL provided her with an opportunity to realize her desires. As a teacher, mother, and wife, she did not have any personal time during the day; sometime between 11:00 pm and 2:00 am, however, she went to INDISCHOOL and shared her stories and concerns with other teachers. In the process of participation, her desires to collaborate and to communicate with other educators were fulfilled.

A regular member teacher with five years teaching experience expressed that her main goal in participating in the community was to find good resources for her students. She found that INDISCHOOL offered the best resources in a readily available form. As a result, she regularly visited the site, searching for new ideas and resources.

A regular member teacher, who has more than 30 years of teaching experience, said she first joined the community to learn what young teachers know, especially 
technology-related skills. However, while she observed young teacher interaction, she found that some teachers could not see the value of teaching or could not solve conflicts with parents. She felt providing guidance or occasional criticism is a duty that she could and should perform, so she kept participating in the community.

As described above, individual teachers' needs varied. However, each participant found that their desires were fulfilled to a certain extent, and the satisfaction encouraged them to more actively participate in INDISCHOOL.

\section{Hindrance-Internal Factors}

In the following sections, we discuss four hindrance factors that prohibited teachers from actively participating in INDISCHOOL. We first explain the internal factors that hindered participation of teachers.

\section{Teachers' Lack of Confidence}

From the researcher note and interview data, we found experienced teachers were afraid of sharing their ideas because they felt that the younger teachers had more innovative ideas. The younger teachers were also hesitant to share their ideas because they thought their lack of experience made their ideas less accurate than the ideas of their experienced counterparts.

Some interviewees reported that teachers were under pressure to share high quality ideas and resources. Participants expressed that the ideas and resources that other teachers shared were very innovative, thus preferring not to share their own ideas because they felt that their work was not unique enough.

\section{Previous Negative Experience in Online} Communities

The posting and interview data showed that previous negative experience of participating in an online community affected participation in another community. For example, a regular member teacher, who has three years of teaching experience, mentioned that she has never posted any message related to her concerns or difficulties in any online Web-boards. She noted one of her colleagues had to leave the school because of a message she posted on an online Web-board - a parent grew upset about the posting and sued the teacher. The interviewee who observed the incident came to believe that the Web was not a safe place to discuss concerns. As a result, she accessed INDISCHOOL only to find and share resources, not to share her personal concerns.

\section{Hindrance-External Factors}

One external factor that hinders teacher participation is identified. 


\section{Lack of Technological Support}

Some participants reported that some of their colleagues were not able to access INDISCHOOL because that INDISCHOOL's technological support was not sufficient. For example, some teachers lost their ID and password and asked the Web managers to inform them of their ID and password. However, no assistance was provided because the Web managers were volunteer teachers, meaning that they were very busy with taking care of their students and administrative work at school. As a result, the teachers who lost their ID and password stopped visiting INDISCHOOL. Some teachers complained that the speed of accessing the site was sometimes slow, to the point of not even being able to log in to the community. From the researcher notes, we found many teachers accessed the community at the same time in the early period of a new school year. Consequently, access was often very challenging, and prevented members from logging in to the site.

\section{Hindrance-Outcome Factors}

Next, we discuss one outcome factor that hinders teacher participation in INDISCHOOL.

\section{Discouraging Teachers' Active Learning}

The downside of online teacher communities is that it could make teachers become information consumers or "stealers," rather than information producers. Because many teachers were willing to share their resources and ideas, teachers could easily gain very creative ideas and ready-to-use teaching materials by just logging into the site and downloading some files. As long as teachers appropriately adapt the ideas and resources into their own class situations, this would help teachers with day-to-day practice to a certain extent. However, interviewees pointed out that some teachers, themselves included, utilized the resources without adaptation, merely printing out the materials without considering their classroom situations and purposes of the lesson.

Overuse of popular resources was also noted as problematic. A regular member teacher, who has three years teaching experience, commented, "I sometimes found that I just downloaded and used resources because they were popular, not because they were useful."

With the use of popular resources, an active member teacher, who has eight years of teaching experience, expressed:

One day, I visited a school and was horrified that students in every class sang the same song following a same flash animation. I could quickly notice that all teachers downloaded the resource from the same Website.

The practical aspect of workshops was also critiqued by several managers. Managers were concerned some INDISCHOOL workshops overemphasized 
practical aspects, such as quick technical teaching tricks, and underemphasized how the skills could enhance students' learning. A manager, who has seven years of teaching experience, noted:

The practical aspect of workshops in INDISCHOOL is the drawback as well as strength of INDISCHOOL. What I noticed was that some teachers did not want to learn a theory. They just wanted to know simple tricks that could quickly draw students' attention. I agree that practice is important but believe that when practices are supported by theories, teachers can help students' learning in a more engaging way. INDISCHOOL should keep trying to find better ways to help professional development of teachers.

\section{IMPLICATIONS OF THE STUDY}

Our initial assumption was that there would be some factors that cultivated online teacher communities which could be found through an investigation of an established online teacher community. Our findings revealed that factors existed which either fostered or hindered a sustainable online community. However, in the process of analyzing each factor, we found that fostering a sustainable online community was more challenging than merely identifying such factors. Consequently, we sought to understand the implication of the factors and the relationships among factors. In this section, we discuss the implications of our findings, including challenges to addressing prescriptive guidance, the interconnectivities of the factors, and the contributions and limitations of the study.

\section{The Challenges to Address Prescriptive Guidance}

We intended to provide prescriptive guidance based on our findings because we noted that most previous findings regarding online communities were descriptive (Schwen \& Hara, 2003). However, providing prescriptive guidance was challenging because most factors were related to members' beliefs or values, which we called internal factors. The problem with the internal factors is that it is almost impossible for others to control someone's beliefs or values. Consequently, providing guidance to help support or eliminate these factors proves difficult.

The amount of time INDISCHOOL members needed to realize the values of their participation revealed how difficult people valued new activities. It took more than two years for new members in INDISCHOOL to actively join the community. Before that, only the initiators and a few teachers participated in sharing and communicating. This finding is consistent with Schlager and Schank's (1997) contention: it takes an enormous amount of time for teachers to feel comfortable with sharing their ideas and experience in online teacher communities.

Our findings indicate that any short-term efforts cannot succeed; people who want to cultivate online teacher communities should understand these internal 
factors and try to endorse support factors and eliminate hindrance factors. For example, to encourage a sense of ownership, INDISCHOOL invites new volunteer Web-board moderators every year. The managers who participated in the interviews suggested this would help build a sense of ownership and provide equal participation opportunities by the members.

\section{The Interconnectivities of the Factors}

In the final analysis, we noted these factors were related to each other. The factors' relationships included between subgroups interconnectivity, within group interconnectivity, and between categories interconnectivity.

The between subgroup interconnectivity referred to the phenomenon that factors in different subgroups were interrelated to each other. For example, one of the internal factors, acknowledging values of participation, was related to the three outcome factors: helping novice teachers become confident educators, assisting in overcoming teacher isolation, and meeting teachers' individual needs. The acknowledgment of these outcome values encouraged members to more actively participate in the community. Furthermore, in the process of active participation, teachers found that student learning as well as their professional development improved. This acknowledgment is the same with the identified internal factor, acknowledging the value of participation. Namely, the outcome factors affected enhancing the internal factor.

We also found that factors within a group interacted with each other, what we have termed within group interconnectivity. For instance, the sense of autonomy in the internal factor subgroup was inextricably tied to the sense of ownership within the same factor subgroup. In other words, when the community has stronger autonomy, the members in the community have a stronger sense of ownership.

Finally, between categories interconnectivity showed that the support and hindrance categories were related. Technology, for example, could be a good support factor when it assisted teachers' participation. However, technology could prevent teachers from active participation when they did not know how to use it. The interconnectivities of the factors are illustrated in Figure 2.

These implications suggested that examining the relationships among factors was as important as identifying individual factors. Our study, however, only focused on identifying individual factors. Consequently, further research is necessary to investigate the impact of the interconnectivities on teacher participation in INDISCHOOL in detail.

\section{Contributions and Limitations of the Study}

This study contributed to the research of online communities of practice in various ways. First, the study identified diverse factors that might nurture a sustainable online teacher community. Having a sense of ownership, which prior 


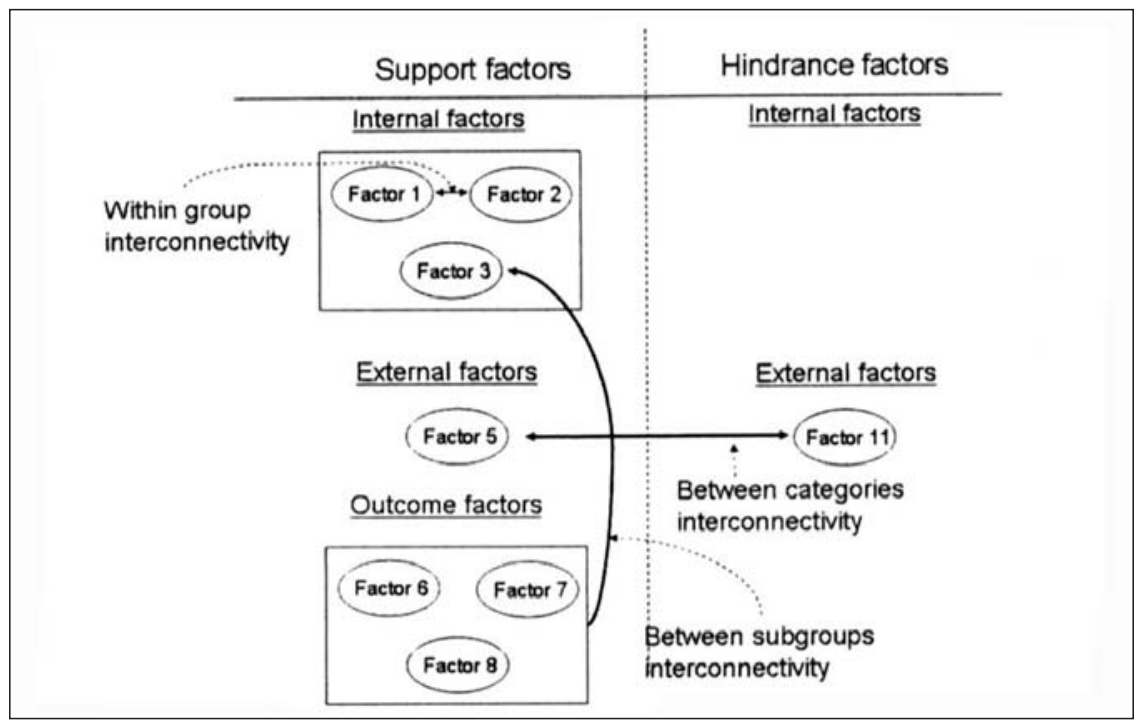

Figure 2. Interconnectivities of the factors.

research has already addressed, and the influence of previous experience in other online communities, which no prior research has addressed, are two such examples. This study also pointed out the aspects teachers appreciate most, including improvement of teacher growth as well as student learning and overcoming teacher isolation. Considering Wenger's (1998) statement- members' values within communities is a key to encouraging the members to sustain in communities, identifying the teachers' values was critical in this study.

Another contribution of the study was identifying factors that could sustain existing online communities because previous research only focused on the creation of online teacher communities. For example, Schlager and Schank (1997) advocated that having a critical mass of members was crucial to creating an online community. However, they could not identify the factors that helped existing communities sustained over an extended period of time.

Despite the significant contributions of our study, it had several limitations, which aligned with limitations of other case studies.

Even though we attempted to recruit various levels of member teachers, the participants of the interviews were predominantly managers and active members. Only a few regular members and lurkers participated in the interviews. We were able to present the voices of advocates for online teacher communities yet failed to fully explore opponents' opinions, i.e., what prevented them from participation. As a result, the hindrance factors that we identified may not be complete; a topic worthy of future study should recruit more regular member teachers and lurkers. 
We noticed that our finding about offline workshops was somewhat limited because we could not observe participants' reactions during the workshops. The finding mostly came from managers' opinions. Consequently, we could not examine how the attendants of the offline workshops perceived the quality and content of the trainings. Examining the offline workshops through observations and interviews with the attendants would have strengthened the study.

A systematic content analysis of the messages posted in the Web-boards would have complemented the interview data. Although the posting data helped us triangulate the interview data, the analysis remains general.

Finally, the results from this study need to be generalized with caution. The study is based on one case in a specific context, which may or may not transfer to other settings (Auyeung, 2004). Further studies are needed to validate a generalization of these findings.

\section{CONCLUSION}

Wenger, McDermott, and Snyder (2002) emphasize the importance of cultivation of communities by providing an analogy: we cannot pull a plant to make it grow faster, yet we can assist its growth by providing enough nutrients and water. Similarly, because communities are self-growing, we cannot force them to grow in certain ways. We can, however, nurture the evolving process by providing some guiding strategies. To nurture the evolving process, identifying support or hindrance factors that affect the sustainability of online teacher communities is crucial.

The purpose of this study was to discover factors related to fostering a sustainable online community for K-12 teachers. This study was conducted through the investigation of INDISCHOOL, which has been sustained over five years. Through in-depth interviews, archived posting examinations, and participation in discussion, we found factors, including eight support and four hindrance factors. In each category, the factors were categorized into three subgroups: internal, external, and outcome factors.

Findings from this study revealed that internal factors, such as having a sense of ownership and autonomy and acknowledging the value of participation, played significant roles in the growth of INDISCHOOL. It was also noted that the value of teachers' participation was related to teachers' beliefs that their active involvement in INDISCHOOL improves student learning. These teachers also reported that INDISCHOOL participation is a valuable part of their professional development.

It is the authors' wish that these empirical findings provide insights for those who facilitate evolving processes of communities of teachers. Although these findings are based on a specific teacher community in Korea, we believe that teachers in other countries can certainly learn from this case in order to support the professional development of K-12 teachers. 


\section{APPENDIX 1: Initial Interview Questions}

For or the initiators:

1. What was the initial purpose of developing the community?

2. Could you briefly explain how INDISCHOOL has been evolved?

3. Why do you think that the popularity of INDISCHOOL is growing?

4. Could you explain the role of off-line communities?

5. What obstacles do you currently face to maintain the community?

6. As a teacher member, how do you participate in the community? (e.g., how often do you visit the site, when do you reply to postings and how do you search new postings.)

7. Do you think that participation in the community influence your classroom teaching? If so, could you explain in what ways participation influence your teaching?

8. How would you define the INDISCHOOL community?

9. What do you think about the future of the INDISCHOOL community?

For other members:

1. How did you first get to know the community?

2. What made you volunteer to support (or actively participate in) the community?

3. Did you introduce the community site to your peers? If so, how was their reaction?

4. What activity do you like most in the community?

5. What are the current purposes for you to come to the site and share your ideas and resources?

6. What hinders you from participating in INDISCHOOL?

7. Are you a member of an off-line community as well? If so, what kinds of activities do you engage in the off-line community?

*We also asked four of the initiators' questions, \# 6, 7, 8, 9 to the other members.

\section{REFERENCES}

Ardichvili, A., Page, V., \& Wentling, T. (2002). Virtual knowledge-sharing communities of practice at caterpillar: Success factors and barriers. Performance Improvement Quarterly, 15(3), 99-113.

Ardichvili, A., Page, V., \& Wentling, T. (2003). Motivation and barriers to participation in virtual knowledge sharing communities of practice. Journal of Knowledge Management, 7(1), 64-77.

Auyeung, L. H. (2004). Building a collaborative online learning community: A case study in Hong Kong. Journal of Educational Computing Research, 31(2), 119-136.

Barab, S. A., MaKinster, J. G., Moore, J., \& Cunningham, D. (2001). Designing and building an online community: The struggle to support sociability in the Inquiry Learning Forum. Educational Technology Research and Development, 49, 71-96. 
Barab, S. A., MaKinster, J. G., \& Scheckler, R. (2003). Designing System Dualities: Characterizing a Web-Supported Professional Development Community. Information Society, 19(3), 237-256.

Barnett, M. (2002). Issues and trends concerning electronic networking technologies for teacher professional development. A critical review of the literature. Paper presented at the annual meeting of the American Educational Research Association, New Orleans, LA.

Borko, H. (2004). Professional development and teacher learning: Mapping the terrain. Educational Researcher, 33(8), 3-15.

Brown, J. S. \& Duguid, P. (2000). The social life of information. Cambridge., MA.: Harvard Business School Press.

Carspecken, P. F. (1996). Critical ethnography in educational research. New York: Routledge.

Cobb, P. (1994). Where is the mind? Constructivist and section perspectives on mathematical development. Educational Researcher, 23(7), 13-20.

DeLacey, B. J., \& Leonard, D. A. (2002). Case study on technology and distance in education at the Harvard Business School. Educational Technology \& Society, 5(2), $13-28$.

Department of Education. (2004). Visions 2020.2: Student views on transforming education and training through advanced technologies.

Dubé, L., Bourhis, A., \& Jacob, R. (2005). The impact of structuring characteristics on the launching of virtual communities of practice. Journal of Organizational Change Management, 18(2), 145-166.

Ellis, D., Oldridge, R., \& Vasconcelos, A. (2004). Community and Virtual Community. Annual Review of Information Science and Technology, 38, 145-186.

Franklin, C. A., \& Sessoms, D. B. (2005). A situative perspective on a collaborative model for integrating technology into teaching. Journal of Educational Computing Research, 32(4), 315-328.

George, J. F., Iacono, S., \& Kling, R. (1995). Learning in context: Extensively computerized work groups as communities-of-practice. Accounting, Management, and Information Technology, 5(3/4), 185-202.

Glaser, B. G., \& Strauss, A. L. (1967). The discovery of grounded theory. Hawthorne, NY: Aldine.

Goldman, S. R. (2001). Professional development in a digital age: Issues and challenges for standards-based reform. Interactive Educational Multimedia, 2, 19-46.

Gray, B. (2004). Informal learning in an online community of practice. Journal of Distance Education, 19(1), 20-35.

Grossman, P., Wineburg, S., \& Woolworth, S. (2001). Toward a Theory of Teacher Community. Teachers College Record, 103(6), 942-1012.

Hara, N. (2000). Social construction of knowledge in professional communities of practice: Tales in courtrooms. Unpublished doctoral dissertation. Indiana University, Bloomington.

Holstein, J. A., \& Gubrium, J. A. (1995). The active interview (Vol. 37). Thousand Oaks/London/New Delhi: Sage Publications.

Hutchins, E. (1991). The social organization of distributed cognition. In L. B. Resnick, J. M. Levine, \& S. D. Teasley (Eds.), Perspectives on socially shared cognition. Washington, DC: American Psychological Association. 
Ingersoll, R. (2003). Who controls teachers' work: Power and accountability in America's schools. Cambridge, MA: Harvard University Press.

Johnson, C. M. (2001). A survey of current research on online communities of practice. Internet and Higher Education, 4, 45-60.

Keller, J. B., Bonk, C. J., \& Hew, K. (2005). The TICKIT to teacher learning: Designing professional development according to situative principles. Journal of Educational Computing Research, 32(4), 329-340.

Kling, R., \& Courtright, C. (2003). Group behavior and learning in electronic forums: A sociotechnical approach. Information Society, 19(3), 221-235.

Korea National Center for Education Statistics \& Information. (2004). Data retrieved July 25, 2005, from http://std.kedi.re.kr/jcgi-bin/publ/publ_yrbk_frme.htm.

Lave, J., \& Wenger, E. (1991). Situated learning. Legitimate peripheral participation. Cambridge: Cambridge University Press.

Lincoln, Y. S., \& Guba, E. G. (1985). Naturalistic inquiry. London: Sage Publication.

Little, J. W. (2002). Locating learning in teachers' communities of practice: Opening up problems of analysis in records of everyday work. Teaching and Teacher Education, $18,917-946$.

McLellan, H. (1996). Situated learning: Multiple perspectives. In H. McLellan (Ed.), Situated learning perspectives. Englewood Cliffs, NJ: Educational Technology Publication.

Ministry of Education \& Human Resources Development. (2003). Adapting education to an information age. A white paper. Retrieved from February 1st, 2005 from the Korean Education \& Research Information Service Website: http://www.keris.or.kr/main/index.jsp.

Putnam, R., \& Borko, H. (2000). What do new views of knowledge and thinking have to say about research on teacher learning? Educational Researcher, 29(1), 4-15.

Rogoff, B. (1994). Developing understanding of the idea of communities of learners. Mind, Culture \& Activity, 1(4), 209-229.

Salmon, G. (Ed.). (1993). Distributed cognition. Psychological and educational considerations. Cambridge: Cambridge University Press.

Schlager, M. S., \& Fusco, J. (2003). Teacher professional development, technology, and communities of practice: Are we putting the cart before the horse? Information Society, 19(3), 203-220.

Schlager, M. S., \& Schank, P. K. (1997). TAPPED IN: A new on-line teacher community concept for the next generation of Internet technology. Paper presented at the second international conference on computer support for collaborative learning, Toronto.

Schwen, T. M., \& Hara, N. (2003). Community of practice: A metaphor for online design? The Information Society, 19, 257-270.

Silverman, D. (2001). Interpreting qualitative data: Methods for analyzing talk, text and interaction. Thousand Oaks, CA: Sage Publications.

Stake, R. (1995). The art of case research. Thousand Oaks, CA: Sage Publications.

Sugar, W. (2005). Instructional technologist as a coach: Impact of a situated professional development program on teachers' technology use. Journal of Technology and Teacher Education, 13(4), 547-571.

Thompson, M. (2005). Structural and epistemic parameters in communities of practice. Organization Science, 16(2), 151-164. 
Wenger, E. (1998). Communities of practice: Learning, meaning and identity. New York: Cambridge University Press.

Wenger, E., McDermott, R., \& Snyder, W. M. (2002). Cultivating communities of practice. Cambridge, MA: Harvard Business School Press.

Westheimer, J. (1998). Among school teachers: Community, autonomy, and ideology in teachers' work. New York: Teachers College Press.

Zhao, Y., \& Rop, S. (2002). A critical review of the literature on electronic networks as reflective discourse communities for inservice teachers, Education and Information Technologies, 6(2), 81-94.

\section{Direct reprint requests to:}

Dr. Jung Won Hur

Department of Instructional Systems Technology

W. W. Wright Education Building, Room 2276

201 North Rose Avenue

Bloomington, IN 47405-1006

e-mail: jwhur@indiana.edu 